\title{
IDENTIFICATION OF LACTOBACILLUS UFV H2B20 (PROBIOTIC STRAIN) USING DNA-DNA HYBRIDIZATION
}

\author{
J.T. de Magalhães ${ }^{1}$; A.P. T. Uetanabaro ${ }^{1}$; C.A. de Moraes $^{2}$ \\ ${ }^{1}$ Departamento de Ciências Biológicas, Universidade Estadual de Santa Cruz, Ilhéus, BA, Brasil; ${ }^{2}$ Instituto de Biotecnologia \\ Aplicada à Agropecuária, Universidade Federal de Viçosa, Viçosa, MG, Brasil.
}

Submitted: April 18, 2007; Returned to authors for corrections: November 12, 2007; Approved: July 04, 2008.

\begin{abstract}
Sequence analyses of the 16S rDNA gene and DNA-DNA hybridization tests were performed for identification of the species of the probiotic Lactobacillus UFV H2b20 strain. Using these two tests, we concluded that this strain, originally considered Lact. acidophilus, should be classified as Lact. delbrueckii.
\end{abstract}

Key-words: Sequencing, probiotic, acid lactic bacteria, hibridization DNA-DNA, Lactobacillus

Lactobacillus species are widely distributed in nature, and some are known for their importance in the food industry and their benefits as probiotic agents in human and animal health (5). To be considered a probiotic agent, a strain must first be characterized and properly identified. The name of the species and strain are generally indicated by the manufacturer, but in many cases, they are not in agreement with the most recent taxonomy of acid lactic bacteria $(12,32)$. This occurs when the bacterial classification is based only on phenotypic characteristics, many times without reproducibility tests and phylogenetic analyses (12). Acid lactic bacteria have low morphological diversity and very similar nutritional and growth requirements, which makes a polyphasic approach very important for species discrimination (29).

Numerous revisions of the acid lactic bacteria nomenclature have shown the wide gap between results obtained by traditional phenotypic tests, such as carbohydrate fermentation, and molecular taxonomy, such as rRNA sequencing $(11,29)$. However, because of low resolution of image sequences, rRNA sequence analysis may not be able to discriminate species of highly related organisms, especially those phenotypically similar $(8,13,22,29)$. Under these conditions, DNA-DNA hybridization, which determines the similarity between two DNA samples, became a reference method to discriminate species and heterogeneous taxa. With the consolidation of molecular techniques, different studies proposed new classifications of various microorganisms $(1,10,14)$ including acid lactic bacteria and lactobacilli (25). The current phylogenetic classification of acid lactic bacteria was determined by rRNA sequencing and DNA-DNA hybridization (29). However, the subdivision of lactobacilli in fermentation groups is still maintained, since fermentation is a main characteristic for the identification and classification of these organisms.

The Lactobacillus UFV H2b20 strain has been the subject of research for its probiotic properties $(19,20,23)$. It was first identified as Lactobacillus acidophilus on account of its sugar fermentation profile (23) and its origin in the human digestive tract. However, a polyphasic approach was required to avoid an equivocal identification of this organism. In the present study, we investigated the identity of the Lactobacillus UFV H2b20 strain, through rDNA sequencing and DNA-DNA hybridization, and confirmed it as Lactobacillus delbrueckii.

Bacterial strains used in this study and their sources are listed in Table 1. Lactobacillus. Cells were harvested by centrifugation, resuspended in TE ( $10 \mathrm{mM}$ TRIS- $\mathrm{HCl}$ and $1 \mathrm{mM}$ EDTA, $\mathrm{pH}$ 8.0) and lysed with $1 \%$ final concentration of SDS after cell wall hydrolysin using $40 \mu \mathrm{g} \mathrm{ml}^{-1}$ lysozyme and $1 \mu \mathrm{g}$ $\mathrm{ml}^{-1}$ mutanolisin (Sigma). RNase A was added to a final concentration of $50 \mu \mathrm{g} \mathrm{ml}^{-1}$ and samples were incubated with $100 \mu \mathrm{g} \mathrm{ml}^{-1}$ proteinase $\mathrm{K}$, for $15 \mathrm{~min}$ at $55^{\circ} \mathrm{C}$. The DNA was extracted with phenol-chloroform: isoamyl alcohol (25:24:1), precipitated with ethanol (24) and resuspended in TE solution.

*Corresponding Author. Mailing address: Universidade Federal de Viçosa, Av PH Rolfs s/n, Viçosa, Minas Gerais, 36570-000, Brazil. Telefone: +5531 3899 2553. Fax: +55 313899 2573. E-mail: camoraes@ufv.br 
Table 1. Bacterial strains used in this work.

\begin{tabular}{lc}
\hline \multicolumn{1}{c}{ Species } & Strain(s) \\
\hline $\begin{array}{l}\text { Lact. delbrueckii } \\
\text { subsp. delbrueckii }\end{array}$ & ATCC $9649^{\mathrm{T}}$ (type strain) \\
$\begin{array}{l}\text { Lact. delbrueckii } \\
\text { subsp. lactis }\end{array}$ & ATCC 12315 \\
Lact. acidophilus & ATCC 4356 ${ }^{\mathrm{T}}$ (type strain) \\
Lactobacillus UFV H2b20 & $\begin{array}{l}\text { Isolated from breast } \\
\text { feeding infant feces* }\end{array}$ \\
\hline
\end{tabular}

ATCC - American Type Culture Collection, Manassas, VA, USA; *Industrial Microbiology Laboratory, BIOAGRO -Universidade Federal de Viçosa, Minas Gerais, Brazil. All bacterial strains were grown on MRS broth (Merck), pH6,5 at $37^{\circ} \mathrm{C}$ for $12 \mathrm{~h}$ and preserved at $80^{\circ} \mathrm{C}$ in fresh MRS broth with $20 \%$ glycerol.

DNA from all the samples was quantified on agarose gel with ethidium bromide. The $16 \mathrm{~S}$ rRNA gene of the $\mathrm{H} 2 \mathrm{~b} 20$ strain was amplified by PCR with the primers FD 5'-CCGAATTCG TCGACAACAGAGTTTGATCCTGGCTCAG-3' and RD 5'CCCGGGATCCAAGCTTAAGGAGGTGATCCAGCC-3' corresponding to conserved regions of eubacterial rDNA extremities (31). Amplification of 16S rDNA was performed in a Perkin Elmer Thermal Cycler in a total volume of $25 \mu$ l containing $20 \mathrm{ng}$ DNA, $1 \mathrm{mM}$ of each primer, $100 \mu \mathrm{M}$ dNTPs, $2 \mathrm{mM} \mathrm{MgCl}_{2}$, $1 \mu \mathrm{g} \mathrm{ml}^{-1}$ bovine serum albumin - BSA (Sigma) and 2.5U Taq DNA polymerase (Promega). The PCR was performed under the following conditions: 25 cycles of $2 \mathrm{~min}$ at $95^{\circ} \mathrm{C}, 50 \mathrm{~s}$ at $50^{\circ} \mathrm{C}$ and $2 \mathrm{~min}$ at $72^{\circ} \mathrm{C}$ and one final 2 -min cycle at $92^{\circ} \mathrm{C}, 50 \mathrm{~s}$ at $50^{\circ} \mathrm{C}$ and $4 \mathrm{~min}$ at $72^{\circ} \mathrm{C}$. The amplified $16 \mathrm{~S}$ rDNA was cloned into PGEM $^{\circledR}$ $\mathrm{T}$ Easy Vector (Promega). Plasmids bearing the insert were purified with kit Wizard ${ }^{\mathrm{TM}}$ Minipreps DNA Purification System (Promega) and were subject to sequencing reactions. Sequencing was done with two kits: Termo Sequenase Dye Terminator Cycle Sequencing Pre-mix Kit (Amersham) and MicroSeq ${ }^{\mathrm{TM}} 16 \mathrm{~S}$ rRNAGene (PE Applied Biosystems) on the ABI Prism ${ }^{\mathrm{TM}} 310$ Genetic Analyzer (Perkin Elmer). Data analyses were done using ABI Prism DNA Sequencing Analysis Software. The rDNA sequence was compared to those available in the GenBank databanks, EMBL Nucleotide Sequence Database (http:// www.ebi.ac.uk/embl), Ribosomal Database Project (15) and BLAST, NCBI (National Center of Biotechnology Information) tools (http://www.ncbi.nlm.nih.gov/cgi-bin/BLAST/nphnewblast) and CSM Molecular Biology Resource (http:// vega.igh.cnrs.fr/bin/lalign-guess.cgi). The sequences were aligned using the CLUSTALW program (28).-About $120 \mathrm{ng}$ of total DNA of each strain was applied on Nylon membrane using the Hybri Slot Blot Manifold as described by the manufacturer (Bio-Rad) (5). The PCR-amplified 16S rDNA, and total DNA of
Lactobacillus UFV H2b20 were labeled with digoxigenin, using the DIG DNA labeling kit (Boehringer Mannheim). The hybridization buffer containing $50 \%$ formamide, $5 \mathrm{X} \mathrm{SSC}(75 \mathrm{mM}$ sodium citrate; $0.75 \mathrm{M} \mathrm{NaCl}, \mathrm{pH} 7.0), 0.1 \% \mathrm{~N}$-laurylsarcosine, $0.02 \%$ SDS and $2 \%$ blocking reagent was used in the hybridization experiment performed overnight at $42^{\circ} \mathrm{C}$. The membranes were washed twice at room temperature for $5 \mathrm{~min}$ in a solution containing $2 \mathrm{X} \mathrm{SSC}(0.03 \mathrm{M}$ sodium citrate and $0.3 \mathrm{M}$ $\mathrm{NaCl}$ ) and $0.1 \% \mathrm{SDS}$, then twice at $68^{\circ} \mathrm{C}$ for $15 \mathrm{~min}$ in $0.1 \mathrm{X} \mathrm{SSC}$, $0.1 \%$ SDS. The detection reaction was carried out using the chemiluminescent substrate CSPD [disodium 3 - (4 methoxyspiro $\{1,2$ - dioxetane - 3, 2" - (5" - chloro) tricyclo [3.3.1.13,7 decan $\}$ - 4 - yl) phenyl phosphate], as recommended by the manufacturer (Boehringer Mannheim). The signal, detected on X-ray film (Kodak X-OTMAT K) exposed at $37^{\circ} \mathrm{C}$ for one hour, was measured using an Ultrascan XL-Enhancer laser densitometer (LKB Bromma) (4).

Analysis by PCR amplification of a 16S rRNA gene copy of $\mathrm{H} 2 \mathrm{~b} 20$ strain with a set of primers designed for Eubacteria (31) yielded a $1519 \mathrm{pb}$ fragment (accession number EF015468). In the sequence analysis, the identity of this DNA, with $99 \%$ identity to $16 \mathrm{~S}$ rDNA, was detached from all four Lact. delbrueckii subspecies from NCBI: Lact. delbrueckii subsp. bulgaricus (accession number AY675257.1), Lact. delbrueckii subsp. lactis (accession number AY050173.1), Lact. delbrueckii subsp. delbrueckii (accession number AY773949.1) and Lact. delbrueckii subsp. indicus (accession number AY421720.1). It bears only $91 \%$ identity with partial sequence of the $16 \mathrm{~S}$ rRNA gene of Lact. acidophilus (accession numbers AY590776, AY186042 and AF375937).

The amount of each DNA in the membranes was verified by prior hybridization using the gene UFV H2b20 16S rDNA as a probe; it was amplified by PCR against total DNAs of Lact. delbrueckii (ATCC 9649 and ATCC 12315) and Lact. acidophilus (ATCC 4356) (Fig. 1A). The signal was 1.5 times weaker in sample 3 because of the different number of copies of $r r n$ operon between the species rather than because of gene similarity. Lact. acidophilus has 4 operons (2) while Lact. delbrueckii has at least 6 operons (18). The identity of $16 \mathrm{~S}$ rDNA from $\mathrm{H} 2 \mathrm{~b} 20$ from the public databanks is similar to the sequences of this same gene in related bacteria.

In the hybridization experiments shown in figure $1 \mathrm{~B}$, total DNA from UFV H2b20 was used as a probe against total DNA of all the samples. The experiment control considered the 100ng total DNA from UFV H2b20 in the membrane. This DNA was $100 \%$ homologous to the probe, i.e., to its own total DNA. All the other hybridization readings were fitted to this pattern (Table 2).

The phylogenetic structure of the acid lactic bacteria was deduced from rRNA sequencing and DNA-DNA hybridization and differs from the physiological and chemotaxonomic classifications used for almost a century (29). The sugar fermentation pattern of the probiotic Lactobacillus placed it 


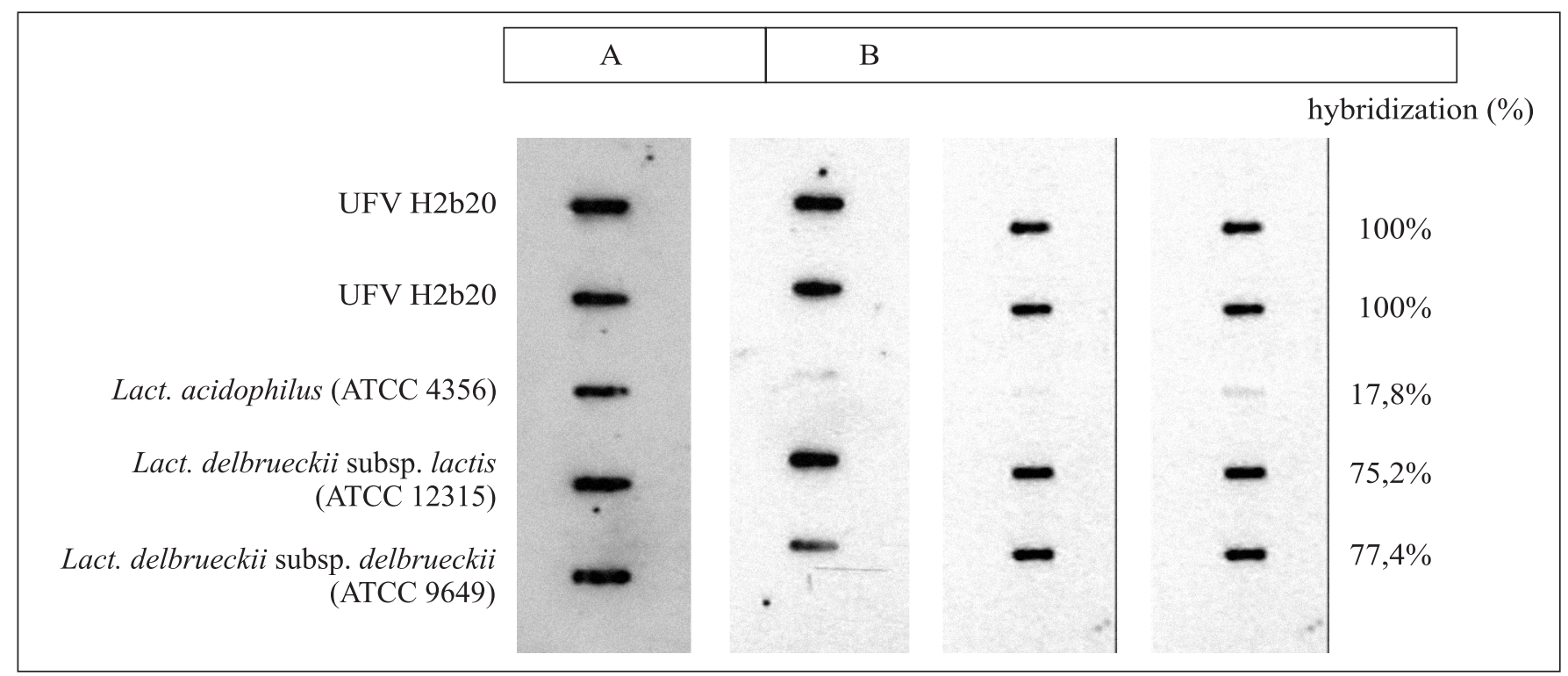

Figure 1. Total DNA hybridization of the studied strains. (A) UFV H2b20 16S rDNA as probe; (B) UFV H2B20 total DNA as probe (three repetitions).

Table 2. Homology (\%) in the hybridizations measured by densitometer and correction according to the amount of DNA in sample membranes.

\begin{tabular}{|c|c|c|c|c|c|c|c|c|c|c|c|}
\hline \multirow[t]{2}{*}{ Sample } & \multirow{2}{*}{$\begin{array}{l}\text { Concentration of } \\
\text { DNA on the } \\
\text { membrane (ng) }\end{array}$} & \multicolumn{3}{|c|}{$\begin{array}{l}\text { Relative surface } \\
\text { of hybridization }\end{array}$} & \multicolumn{3}{|c|}{ Corrected value } & \multicolumn{3}{|c|}{ Homology $(\%)$} & \multirow[t]{2}{*}{$\begin{array}{c}\text { Homology } \\
\text { average }\end{array}$} \\
\hline & & 1 & 2 & 3 & 1 & 2 & 3 & 1 & 2 & 3 & \\
\hline UFVH2B20 & 100 & 26.02 & 27.97 & 26.08 & 26.02 & 27.97 & 26.08 & 100.0 & 100.0 & 100.0 & 100.0 \\
\hline Lact. acidophilus & 64 & 3.3 & 2.82 & 3.01 & 5.15 & 4.4 & 4.7 & 19.8 & 15.73 & 18.0 & 17.8 \\
\hline $\begin{array}{l}\text { Lact. delbrueckii } \\
\text { subsp. lactis } \\
\text { Lact. delbrueckii }\end{array}$ & 125 & 25.75 & 23.58 & 25.84 & 20.6 & 18.8 & 20.67 & 79.1 & 67.21 & 79.3 & 75.2 \\
\hline subsp. delbrueckii & 89 & 16.93 & 18.85 & 19.44 & 19.0 & 21.17 & 21.84 & 73.0 & 75.6 & 83.7 & 77.4 \\
\hline
\end{tabular}

closest to Lact. acidophilus (23), an identification that was accepted at the time because of the strain's probiotic properties and also because it was originally isolated from a breastfeeding infant's fecal matter. There is a close phylogenetic relationship between Lact. delbrueckii subsp. bulgaricus and Lact. acidophilus, and confusion between their nomenclature is common (9). Hence, the need for unequivocal identification motivated PCR amplification of a 16S rRNA gene of H2b20 strain.

Many times, the analysis of rRNA sequence may not differentiate closely related organisms, especially those with similar phenotypes, because of the low quality of sequence resolution $(22,29)$. The correlation between DNA-DNA hybridization and homology to rDNA $16 \mathrm{~S}$ is, in many cases, non-linear, i.e., distinct species may have high similarity in rDNA $16 \mathrm{~S}$ sequences. Likewise, low DNA-DNA homology does not necessarily indicate low similarity of rDNA $16 \mathrm{~S}$ among the strains, since this gene contains sequences that are preserved in the different bacteria groups $(6,16,26)$.

Studies using DNA-DNA hybridization have been used do describe new species and have contributed to the reduction of former heterogeneous taxa. Hence, the use of this technique is indispensable to clear up taxonomic uncertainties over acid lactic bacteria, especially in genus Lactobacillus (25). Although some authors currently consider that the resolution power of 
this technique is high, it is suggested that rRNA sequencing may be carried out as well to increase confidence in the results $(21,27)$. A classic example is the bacteria Lact. Casei (17). In the present study, to guarantee a strain's classification, both $16 \mathrm{~S}$ rDNA homology analysis and DNA-DNA hybridization were used and the results show agreement in classifying the UFV $\mathrm{H} 2 \mathrm{~b} 20$ strain as Lact. delbrueckii.

A re-association above $70 \%$ between two strains indicates that they belong to a same species, given that organisms with $70-100 \%$ DNA similarity have at least $96 \%$ similarity in sequence identity $(3,27,30)$. These values depend strongly on experimental conditions and reflect only an indirect measure of homologies of DNA sequences. The stringency of the reaction is determined by salt and formamide concentrations, temperature and molar $\mathrm{G}+\mathrm{C}$ content of the DNA used. The hybridizations are usually carried out under standard conditions that are not necessarily optimal or stringent for all the bacteria. As a rule, it was determinate that a temperature of $25^{\circ} \mathrm{C}$ under sample $\mathrm{Tm}$ is required to achieve optimal conditions for renaturation or hybridization. The temperature value decreases about $0.7^{\circ} \mathrm{C}$ per percentage point of formamide added to the hybridization solution, and the formamide's concentration is associated to the $\mathrm{C}+\mathrm{G}$ content of the DNA. Hence, hybridizations are usually carried out with 5 or $6 \mathrm{X} \mathrm{SSC}, 40-50 \%$ formamide at around $42^{\circ} \mathrm{C}$. These conditions would be acceptable for DNAs with about 45 $\mathrm{mol} \% \mathrm{G}+\mathrm{C}$ and suboptimal for DNAs with higher or lower amounts of these bases (7). Although a range of protocols have described this technique, in many cases it is not clear if the hybridization used was optimal, suboptimal or stringent for the organism studied. Bacteria from acid lactic belong to a branch of the Clostridium group that contains low $\mathrm{G}+\mathrm{C}$ amounts (from 32 to $50 \%$ ). The molar percent of $\mathrm{G}+\mathrm{C}$ in Lact. acidophilus is $36 \%$, while in Lact. delbrueckii, which is considered the group with the highest $\mathrm{G}+\mathrm{C}$ percent, this value is $50 \%(5,29)$. We can thus consider that the hybridization conditions used were optimal for the species studied.

When bacteria species share common phenotypical properties, between 30 and $65 \%$ homology would support the idea that they belong to a same genus (3). Therefore, because the hybridization value of $\mathrm{H} 2 \mathrm{~b} 20$ was $30 \%$ lower than that of the reference strain of Lact. acidophilus, it could not indicate that $\mathrm{H} 2 \mathrm{~b} 20$ belonged to another genus. The Lactobacillus species have different genotypes showing low degree of DNA-DNA homology to each other. Lact. helveticus is similar to Lact. acidophilus in its $\mathrm{G}+\mathrm{C}$ content and in various biochemical characteristics. Nevertheless, Lact. helveticus has only 13 to $44 \%$ of DNA-DNA homology with the different genotypes of Lact. acidophilus (lato sensu), which contain Lact. acidophilus (stricto sensu), Lact. gasseri, Lact. crispatus, Lact. amylovorus, Lact. gallinarum and Lact. johnsonii species. This discrepancy in homology values could also be found among the members themselves of this group, with values varying from 20 to $50 \%(10,29)$.
Therefore, the results presented here support that the previous classification of the Lact. delbrueckii strain studied should be abolished.

\section{ACKNOWLEDGEMENTS}

We also thank the Dr. Rosato, Y.B. and Dr. Gonçalves, E.R., CBMEG, UNICAMP, São Paulo, Brazil for kindly providing assistance in the sequence analysis.

\section{RESUMO}

\section{Identificação de Lactobacillus UFV H2b20 (linhagem probiótica) através de hibridização DNA-DNA}

Análise da seqüência do gene 16S rDNA e ensaios de hibridização DNA_DNA foram empregados para identificar a espécie da cepa probiótica Lactobacillus UFV H2b20. Empregando-se estes dois testes, concluímos que esta cepa, originalmente considerada Lact. acidophilus, deve ser classificada como Lact. delbrueckii.

Palavras-chaves: Sequenciamento, probiótico, bactéria do ácido láctico, hibridização DNA-DNA, Lactobacillus

\section{REFERENCES}

1. Bringel, F.; Curk, M.C.; Hubert, J.C. (1996). Characterization of lactobacilli by southern-type hybridization with a Lactobacillus plantarum pyr DFE probe. Int. J. Syst. Bacteriol., 46: 588-594.

2. El-Osta, Y.G.A.; Hillier, A.J.; Dobos, M. (2005). Construction of a combined physical and genetic map of the chromosome of Lactobacillus acidophilus ATCC 4356 and characterization of the rRNA operons. Microbiology, 151: 875-892.

3. Grimont, P.A.D. (1983). Les colloques de l'INSERM 114, 47.

4. Gonçalves, E.R.; Rosato, Y.B. (2000). Genotypic characterization of Xanthomonas strains isolated from passion fruit plants (Passiflora ssp.) and their relatedness to different Xanthomonas species. Int. $J$. Syst. Evol. Microbiol., 50: 811-821.

5. Hammes, W.P.; Weiss, N.; Holzapfell, W. (1992). The genera Lactobacillus and Carnobacterium. In: Balows, A., Truper, H.G., Dworkin, M., Harder, W., Schleifer, K. (eds). The prokaryotes, a handbook on the bioloby of bacteria: ecophysiology, isolation, identification, applications. vol. II, Springer, New York, p. 15351573

6. Hiraishi, A.; Nagashima, K.V.P.; Matsuura, K.; Shimada, K.; Takaichi, S.; Wakao, N.; Katayama, Y. (1998). Phylogeny and photosynthetic features of Thiobacillus acidophilus and related acidophilic bacteria: its transfer to the genus Acidiphilium as Acidiphilium acidophilum comb. nov. Int. J. Syst. Bacteriol., 48: 1389-1398.

7. Jahnke, K.D. (1994). A modified method of quantitative colorimetric DNA-DNA hybridization on membrane filters for bacterial identification. J. Microbiol. Methods, 20: 273-288.

8. Johansson, M.L.; Quednau, M.; Ahrné, S.; Molen, G. (1995). Classification of Lactobacillus plantarum by restriction endonuclease analysis of total chromosomal DNA using conventional agarose gel electrophoresis. Int. J. Syst. Bacteriol., 45: 670-675.

9. Klaenhammer, T.; Altermann, E.; Arigoni, F.; Bolotin, A.; Breidt, F.; Broadbent, J.; Cano, R.; Chaillou, S.; Deutscher, J.; Gasson, M.; Van 
de Guchte, M.; Guzzo, J.; Hartke, A.; Hawkins, T.; Hols, P.; Hutkins, R.; Kleerebezem, M.; Kok, J.; Kuipers, O.; Lubbers, M.; Maguin, E.; Mckay, L.; Mills, D.; Nauta, A.; Overbeek, R.; Herman, P.; Pridmore, D.; Saier, M.; Van Sinderen, D.; Sorokin, A.; Steele, J.; O'Sullivan, D.; De Vos, W.; Weimer, B.; Zagorec, M.; Siezen, R. (2002). Discovering lactic acid bacteria by genomics. Antonie van Leeuwenhoek, 82: 29-58.

10. Kandler, O.; Weiss, N. (1986). Genus Lactobacillus Beijerinck 1901, 212. In: Sneath, P.H.H., Mair, N.S., Sharpe, M.E., Holt, J.G. (eds) Bergey's Manual of Systematic Bacteriology, vol. 2, Baltimore, Williams e Wilkins, p. 1209-1234.

11. Klein, G.; Bonaparte, C.; Reuter, G. (1994). Lactobacillus. In Freney, J.; Reanud, F.; Hansen, W.; Bollet, C. (eds) Manuel de Bactériologie Clinique, vol. II, Amsterdam: Elsevier, p. 885-897.

12. Klein, G.; Pack, A.; Bonaparte, C.; Reuter, G. (1998). Taxonomy and physiology of probiotic lactic acid bacteria. Int. J. Food Microbiol., 41: 103-125.

13. Klijn, N.; Weerkamp, H.; De Vos, W.M. (1991). Identification of mesophilic lactic acid bacteria by using polymerase chain reaction amplified variable regions of 16S rRNA and specific DNA probes. Appl. Environ. Microbiol., 57: 3390-3393.

14. Leblond-Bourget, N.; Philippe, H.; Mangin, I.; Decaris, B. (1996). 16S rRNA and $16 \mathrm{~S}$ to $23 \mathrm{~S}$ internal transcribed spacer sequence analysis reveal inter-and intraspecific Bifidobacterium phylogeny Int. J. Syst. Bacteriol., 46: 102-111.

15. Maidak, B.L.; Cole, J.R.; Parker, C.T.; Garrity, G.M.; Larsen, N.; Li, B.; Lilburn, T.G.; MacCaughey, M.J.; Olsen, G.J.; Overbeek, R.; Pramanik, S.; Schmidt, T.M.; Tiedje, J.M.; Woese, C.R. (1999). A new version of the RDP (Ribosomal Database Project). Nucleic Acids Res., 27: 171-173.

16. Metha, A.; Rosato, Y. (2001). Phylogenetic relationships of Xylella fastidiosa strains from different hosts, based on 16S rDNA and 16S23S intergenic spacer sequences. Int. J. Syst. Evol. Microbiol., 51: 311-318.

17. Mori, K.; Yamazaki, K.; Ishiyama, T.; Katsumata, M.; Kobayashi, K.; Kawai, Y.; Inoue, N.; Shinano, H. (1997). Comparative sequences analyses of the genes coding for rRNA 16S of Lactobacillus caseirelated taxa. Int. J. Syst. Bacteriol., 47: 54-57.

18. Moschetti, G.; Blaiotta, G.; Aponte, M.; Mauriello, G.; Villani, F.; Coppola, S. (1997). Genotyping of Lactobacillus delbrueckii subsp. bulgaricus and determination of the number and forms of $r r n$ operons in L. delbrueckii and its subspecies. Res. Microbiol., 148: 501-510.

19. Moura; L.N.; Neumann, E.; Quercia, L.Q.; Nicoli, J.R. (2001). Protection by Lactobacilllus acidophilus UFV H2b20 against experimental oral infection with Salmonella enterica subsp.enterica ser. typhimurium in gnotobiotic and conventional mice. Braz. J. Microbiol., 32: 66-69.

20. Neumann, E.; Oliveira, M.A.P.; Cabral, C.M.; Moura, L.N.; Nicoli, J.R.; Vieira, E.C.; Cara, D.C.; Podoprigora, G.I.; Vieira, L.Q. (1998).
Monoassociation with Lactobacillus acidophilus UFV H2b20 stimulates the immune defense mechanisms of germfree mice. Braz. J. Med. Biol. Res., 31: 1565-1573.

21. Niamsup, P.; Sujaya, I.N.; Tanaka, M.; Sone, T.; Hanada, S.; Kamagata, Y.; Lumyong, S.; Assavanig, A.; Asano, K.; Tomita, F.; Yokota, A. (2003). Lactobacillus thermotolerans sp. nov., a novel thermotolerans species isolated from chicken faeces. Int. J. Syst. Evol. Microbiol., 53: 263-268.

22. Pot, B.; Hertel, C.; Ludwig, W.; Descheemaeker, P.; Kersters, K.; Schleifer, K. (1993). Identification and classification of Lactobacillus acidophilus, L. gasseri and L. johnsonii strains by SDS-PAGE and rRNA-targeded oligonucleotide probe hybidization. J. Gen. Microbiol., 139: 513-517.

23. Sabioni, N.S.S.; Pinheiro, A.J.R.; Teixeira, M.A. (1998). Acidophilus milk: Isolation and characterization of Lactobacillus acidophilus from breast-fed children and from calves' feces. Braz. J. Microbiol., 19: 393-398.

24. Sambrook, J.; Fritsch, E.F.; Maniatis, T. (1989). Molecular cloning. A Laboratory Manual. 2nd ed. New York, Cold Spring Harbor Laboratory Press, v. 1-3.

25. Sarra, P.G.; Magri, M.; Bottazzi, V.; Dellaglio, F. (1980). Genetic heterogeneity among Lactobacillus acidophilus strains. Antonie van Leeuwenhoek, 46: 169-176.

26. Sessitsch, A.; Ramirez-Saad, H.; Hardarson, G.; Akkermans, A.D.L.; De Vos, W.M. (1997). Classification of Austrian rhizobia and the Mexican isolate FL27 obtained from Phaseolus vulgaris L. as Rhizobium gallicum. Int. J. Syst. Bacteriol., 47: 097-1101.

27. Stackebrandt, E.; Goebel, B.M. (1994). Taxonomic notes: a place for DNA-DNA reassociation and 16S rRNA sequence analysis in the present species definition in bacteriology. Int. J. Syst. Bacteriol., 44: 846-849.

28. Thompson, J.D.; Higgins, D.G.; Gibson, T.J. (1994). Clustal W: improving the sensitivity of progressive multiple sequence alignment through sequence weighting, position specific gap penalties and weight matrix choice. Nucleic Acids Res., 22: 4673-4680.

29. Vandamme, P.; Pot, B.; Gillis, M.; De Vos, P.; Kersters, K.; Swings, J. (1996). Polyphasic taxonomy, a consensus approach to bacterial systematics. Microbiol. Rev., 60: 407-438.

30. Wayne, L.G.; Brenner, D.J.; Colwell, R.R.; Grimont, P.A.D.; Kandler, O.; Krichevsky, M.I.; Moore, L.H.; Moore, W.E.C.; Murray, R.G.E.; Stackebrandt, E.; Starr, M.P.; Trüper, H.G. (1987). Report or the Ad $H o c$ committee on reconciliation of approaches to bacterial systematic. Int. J. Syst. Bacteriol., 37: 463-464.

31. Weisburg, W.G.; Barns, S.M.; Pelletier, D.A.; Lane, D.J. (1991). 16S ribosomal DNA amplification for phylogenetic study. J. Bacteriol., 173: 679-703.

32. Yeung, P.S.M.; Sanders, M.E.; Kitts, C.L.; Cano, R.; Tong, P.S. (2002). Species-specific identification of commercial probiotic strains. American Dairy Science Association, 85: 1039-1051. 